\title{
Individuumok és álindividuumok az interneten
}

\section{Reflexiók a digitális nomádok Janus-arcú közegéről}

A cikk megvizsgálja a virtuális és reális világ határán mozgó individuumok viszonyainak elmúlt húszévnyi változását a digitális hálózati média fejlődésének tükrében.

Bár kezdetben úgy tűnt, hogy a mobil információs társadalom technológiái a modernségben nem hoztak sok változást az individualitás kifejeződése szempontjából, az elmúlt húsz év árnyalta a képet. A virtualitás és realitás határán egyensúlyozó individuum már nem két világ polgára, hanem egyé, amely magába foglalja a konvergáló virtualitást és realitást. A tér- és időkereteket már nem uralják a „digitális nomádok”: a virtualitás és a realitás korábban szétválasztható színterei egyetlen világgá állnak össze.

A digitális hálózati média humán ágensei mellett a hálózat technológiai gépi ágensei mindinkább egyenrangú partnerekké válnak. A digitális nomád metaforája ezért sem állja már meg a helyét: aki korábban egyedül vándorolt a feltáratlan, kiaknázatlan területeken, most számtalan társsal együtt - úgy más individuumokkal, mint gépi ágensekkel - halad, és „nomádsága”, szabadsága már csak látszólagos. A gépi ágensek sokasodása miatt ember és gép szimbiózisa a jövőben fokozódni látszik, új megbékélés igényét támasztva emberi és gépi ágensek között.

Kulcsszavak: digitális nomád, mesterséges intelligencia, gépi ágens, digitális hálózati média, virtuális valóság

Szerzői információ

Bokor Tamás, PhD, Budapesti Corvinus Egyetem

Orcid: https://orcid.org/0000-0001-8221-1212

Így hivatkozzon erre a cikkre:

Bokor Tamás. „Individuumok és álindividuumok az interneten”. Információs Társadalom XXI, 1. szám (2021): 73-87.

$=$ https://dx.doi.org/10.22503/inftars.XXI.2021.1.3

A folyóiratban közölt müvek

a Creative Commons Nevezd meg! - Ne add el! - Így add tovább! 4.0

Nemzetközi Licenc feltételeinek megfelelően használhatók. 


\section{Individuals and pseudo-individuals on the Internet}

The article observes the changes in the relationships of individuals moving on the border of the virtual and real world over the past twenty years considering the development of digital network media.

Although it seemed earlier that the technologies of the mobile information society in modernity did not bring much change in terms of the expression of individuality, the last twenty years have nuanced the picture. The individual balancing on the border of virtuality and reality is no longer a citizen of two worlds, but one that includes converging virtuality and reality. Spatial and temporal frameworks are no longer dominated by "digital nomads": the previously separable and separated scenes of virtuality and reality merge into a single world.

Besides the human agents of digital network media, the machine agents of the network are increasingly becoming equal partners. The metaphor of the digital nomad is therefore no longer valid: he who used to wander alone in unexplored, untapped areas is now moving with countless companions, both other individuals and machine agents, and his "nomadism," his freedom remain apparent. Due to the proliferation of machine agents, the symbiosis of man and machine seems to increase in the future, raising the need for new reconciliation between human and machine agents.

Keywords: digital nomad, artificial intelligence, machine agent, digital network media, virtual reality 


\section{Bevezetés: két évtized a digitális hálózati médiában ${ }^{1,2}$}

Húsz év telt el azóta, hogy megjelent Manuel Castells, az információs társadalom egyik fő teoretikusának Az Internet-galaxis. Gondolatok az internetről, üzletről és társadalomról című kötete (Castells 2001). A könyv címe, visszautalva Marshall McLuhan 1962-es Gutenberg-galaxisára (McLuhan 2001), amellett foglal állást, hogy az internet a könyvnyomtatáshoz hasonló társadalmi változásokat hozott a társadalmi és a gazdasági életbe.

Szintén húsz év telt el az Információs Társadalom folyóirat első számának megjelenése óta, amelyben Karácsony András az individualitás mibenlétét boncolgatta „a nomádok földjére”, azaz a virtuális valóságra vonatkoztatva (Karácsony 2001). A társadalom és a gazdaság egyértelmű és gyors változásai mellett két évtizeddel ezelőtt még kérdésesek voltak az egyének életének azon változásai, amelyeket az internetnek tulajdoníthatunk. Végkövetkeztetésként a tanulmány megállapította: „a mobil információs társadalom technológiái oly sok változást nem hoztak a modernségben. Sem több, sem kevesebb lehetőséget nem adnak az individualitás kifejeződésének" (Karácsony 2001, 66.).

Húsz év telt el azóta, hogy a VeriSign bejelentése szerint a jövőben mindenki a nemzeti nyelvének megfelelően (például tetszőleges ékezetekkel) írhatja le a domainnevét. Jelentős lépés volt ez a „glokális” és nemzeti nyelvű internet fejlődésének irányába. Ugyanebben az évben a New York-i World Trade Center ikonikus ikertornyait elpusztító terrortámadás jelezte előre a kultúrák összecsapását, az egypólusú világ veszélyeit és az online szervezett terrorizmus erősödését. Az Úrodüsszeia cselekményének évében már világos volt: mégsem a Föld bolygón kívül keresendő az új civilizációs veszély, hanem köztünk, a modernitás emberei között, egy bizonytalan tér-idő koordinátarendszerben, amelyet digitális hálózati médiának is nevezhetünk.

„Az első tízesben a világot láttuk meg; 1991-től rácsodálkoztunk erre, aztán a 2001-től kezdődő tíz évben beletanultunk" - összegezte a magyar internet első húsz évének történetét Bohus Mihály (Varga 2011, 52.). Hasonló történt a 2001 és 2021 közötti időablakban is: az első tíz évben rácsodálkoztunk mindazokra a hatásokra, amelyeket az internet gyakorolt az individuumokra (Turkle 1999), majd 2011-től beletanultunk az internet mindennapos használatának folyamataiba. 2021-ben, túl néhány további jelentős társadal-

\footnotetext{
${ }^{1}$ A tanulmány Karácsony (2001) és Bokor (2010) cikkeinek továbbgondolásából született.

2 A „digitális hálózati média” fogalma pontosan nevezi meg egyfelől az online médiakommunikáció technológiai sajátosságát (a digitálisan kódolt információk feldolgozását) mint eszközök közötti közös nevezőt, másfelől annak legfőbb tartalmi jellegzetességét (a hálózatiságot) mint a használati módok összességét leíró jellemzőt. Ennyiben nagyon közel áll ahhoz a felfogáshoz, amely DiMaggio és mtsai. (2001) munkájában jelenik meg, és amely mellett a szerző korábban már elköteleződött (Bokor 2011), tudniillik, hogy az internet egyszerre írható le technológiai infrastruktúraként és használati módok összességeként.
} 
mi változáson és lassan-lassan kilábalva egy globális traumából, amelyben jelentős szerep hárult a digitális technológiákra, ideje van az ismételt reflexiónak: hogyan áll ma a modern ember és a digitális valóság viszonya? Nomád-e még a digitális nomád, aki a virtuális valóságban egyedül vándorolva szabadon deríti fel a terepet? Valóban nem kínál-e ma a modernitásban a mobil információs technológia sem több, sem kevesebb lehetőséget az individualitás kifejeződésére, mint amennyi a modernitás előtti időkben rendelkezésre állt?

Karácsony András tanulmánya először feltárta az individualitásminták és a realitás rétegzettségének viszonyát, valamint a kommunikáció problémáját a tér és idő újféle jelentéstartományainak tükrében. Ezt követően röviden szólt az internet világának nomád jellegéről, az ismerős és ismeretlen, a bizalmas és bizalmatlan megkülönböztetésének problémáiról, végül pedig arról, hogy a hálón keresztüli kommunikációban a modern társadalom jelenközpontúsága fejeződik ki.

Az írás felveti, hogy miként azonosítják az individuumot azok, akikkel kommunikatív viszonyban áll. A weben az individuum a kommunikációs csatornák redukált jelenléte miatt ugyan csak részlegesen mutatkozik, de szellemének lényege - állítja Karácsony - a webtől érintetlen marad, ennélfogva lényegében ugyanúgy azonosítják egymást az individuumok, ahogyan azt a realitásban teszik. Szintén felvetődik, hogy mennyiben uralja az egyén azokat a téri és időkereteket, amelyeket a digitális felületek kínálnak számára. A digitális nomád egy kiterjesztett jelen időben él, amelyben a tér és az idő fogalma is szimbolikussá válik. Ezzel összefüggésben kérdez rá a húszéves cikk arra, hogy mi alapján bízunk egy weboldal szövegében, míg a másikéban nem, és megállapítja: erről oly sok információval még nem rendelkezünk. Marad-e még bizalom akkor, ha a tudás hordozója nem megszemélyesíthető? Ez utóbbi kérdésre az írás nem ad kategorikus választ, de kiemeli, hogy személyes tudásunk világában a digitális térből származó információk legtöbbje nem ellenőrizhető, és ez problémákat vet fel a tudás és a bizalom témakörében.

Jelen tanulmány szerzője azt állítja, hogy mivel a digitális hálózati média humán ágensei mellett a hálózat technológiai gépi ágensei egyre önállóbbakká, mindinkább egyenrangú partnerekké válnak, a modernitásban a digitális hálózati média a maga Janus-arcú módján szűkíti az individuum önkifejezési lehetőségét. Bár az individuumok lényege továbbra is érintetlen a digitális hálózati médiától, a gépi ágencia egyre növekvő hatással formálja át őket. A tér- és időkereteket már nem uralják a felhasználók: a virtualitás és a realitás egyetlen világgá áll össze, amely meghatározza kereteinket. A digitális létünkből származó tudás hordozói a legritkább esetben személyesíthetők meg, sőt immár az sem biztos, hogy humán ágenshez kötődnek. Ennek következményeként a tudás helyett a hitek és a bizalom kerülnek előtérbe, a digitális hálózati média humán és gépi ágensei között új viszonyrendszer alakul ki. 


\title{
Ember és gép: interakciók és intenciók sürüjében
}

\author{
„Uploaded to the cloud, sounds like heaven.” \\ - Black Mirror, 3. évad (Brooker 2016)
}

„A széleskörü internethasználat megváltozott kultúráról, emberi természetről, közösségi és személyes viszonyokról tanúskodik. Mindezek együttes érvényesülésének következtében az internethasználat kifejezi és elősegíti egy új emberi létforma létrejöttét, amelyet hálólétnek nevezünk” (Ropolyi 2020, 247.). A digitális hálózati média jelenléte egyre erősödik: ahelyett, hogy mellettünk lenne, inkább velünk, rajtunk, bennünk van. Nemhogy a mindennapok része lett, hanem - kezdetben némelyek, majd a pandémia alatt egyre többek számára - már-már a túlélés eszköze. A tanulás, a munka és a gazdaság életben maradása (például a kereskedelem hőfokának viszonylagos fenntartása) szempontjából kulcsfontosságú szereppel bír. Közhelyesülését mi sem mutatja jobban, mint köznevesülése: keveseknek jut eszébe ma már nagy kezdőbetűvel írni az internetet.

Az ember és ember közti kommunikáció mellett régóta definiált viszony az ember és gép közti kommunikáció, amelynek fő formája korunkban a human-computer interface-en keresztül valósul meg (Manovich 2001). Az ember-gép kommunikáció immár hasonló kontingenciával, esetlegességgel, bizonytalansággal bír, mint a humán-humán párbeszéd. Ember és gép dialógusa a humán-humán dialógushoz hasonlóan interpenetrációs viszony (Luhmann 2009), mert az ember és a gép kommunikációi kölcsönösen egymásba hatnak, szemben a korábbi ember-gép interakciókkal, amelyek során az emberi kommunikáció egyértelműen erősebb hatással bírt a gépre nézve, mert nagyobb kontrollt tudott gyakorolni felette, mint fordítva. A résztvevő felek hierarchiája az aszimmetria helyett fokozatosan egyre szimmetrikusabb jegyeket mutat: a digitális hálózati eszközökkel folytatott kommunikációink, például hogy milyen tartalmakat kínál fel számunkra egy intelligens algoritmus, lassanként épp annyira egyediek, személyre szabottak és pillanatfüggők, mint amennyire kontextusfüggők az emberek között zajló (akár digitális hálózati eszközökön történő) társalgás mozzanatai.

Az ember-gép kommunikáció szimmetriájának erősödésében nagy szerepe van az automatizáció, a robotika és a mesterséges intelligencia fogalomhármasának, amely lassan, de biztosan autonóm ágenssé teszi a digitális technológiákat. Az EU-nak a robotikára vonatkozó 2020-as stratégiája így fogalmaz: „A robotikai technológia dominánssá fog válni a következő évtizedben. A munkahelyek és az otthonok minden vetületét befolyásolni fogja. A robotikában megvan a lehetőség arra, hogy átalakítsa életünket és munkafolyamatainkat, javítsa a hatékonyságot és a biztonságot, magasabb színvonalú szolgáltatásokat nyújtson, és munkahelyeket teremtsen. A hatása idővel egyre növekedni fog, és egyre intenzívebb lesz a robotok és emberek közötti interakció is” (European Agency for Safety and Health at Work 2020). 
E növekvő hatás és az egyre intenzívebb ember-gép interakció ahhoz vezet, hogy a gépi intelligencia potenciálisan felzárkózhat az emberihez, vagy legalábbis megközelítheti azt, valamint hogy a gépi tanulás következtében az emberi felhasználók számára egyre kevésbé átlátható és követhető a digitális hálózati média struktúrája és a benne áramló információk eredete és célja. A 2010-es években e folyamat felgyorsulását platformizációnak kezdték nevezni (Helmond 2015): a közösségi média oldalai (social network sites, SNS) interaktív weboldalakból egységes, domináns infrastrukturális és gazdasági modellé álltak össze, amely platformot szolgáltat minden webes tartalom számára. E platform tulajdonosi szerkezete, a tartalomszerkesztés mögött meghúzódó döntések és motivációk, az algoritmikus irányítottság sajátosságai elrejtőznek a platform mögött, a struktúra megfigyelhetetlensége és hozzáférhetetlensége pedig magával hozza a kiszolgáltatottságot. Mindaddig ugyanis, ameddig az internetet úgy írhattuk le, mint számítógépek egybekapcsolt és kizárólag humán ágensek által üzemeltetett hálózatát, a virtuális valóság vándorai joggal feltételezhettek emberi intenciókat a tartalmak mögött. Mára azonban annyira jelentős arányban találhatóak gépi ágensek (például chatbotok) és automatikusan létrejött tartalmak (például deepfake-videók) a világhálón, hogy ennek nyomán felmerül a kérdés: honnan tudjuk, hogy mely tartalom létrejöttéhez rendelhető hozzá tudatos emberi szándék, és melyhez nem? Egyáltalán: honnan tudható, hogy mely tartalom született emberi, és melyik gépi intelligencia hatására?

\section{Polikontexturalitás a létrétegek között}

„There are only two industries that call their customers "users«: illegal drugs and software." — Edward Tufte (The Social Dilemma [Orlowsky 2020])

A digitális térben az emberi és gépi intelligencia közeledése folytán a megfigyelő és a megfigyelt szerepe egyre inkább közelít egymáshoz, és ebben az internet realityben, digitális Panoptikonban a megfigyelő sosem tudhatja biztosan, hogy mikor és milyen formában kerül be a megfigyeltek csoportjába. A megfigyelő és a megfigyelt individuum kategóriái logikai „és”-sel kapcsolódnak egybe, majd egészen össze is csúsznak. Akár algoritmus, akár hacker, akár hatóság gyűjt adatokat a userről, mindenképpen megfigyelhetővé válik, ezért előbb-utóbb megfigyelés tárgya lesz. Digitális lábnyomait önkéntelenül, tudtán és akaratán kívül bocsátja közszemlére.

A hálózatnak lényeges tulajdonsága a komplexitás, a robusztus felépítmény (azaz a nehezen pusztítható architektúra), és a decentralizáltság. Habár ez utóbbiból következik a források ismeretlensége, az ellenőrizhetőség elégtelensége, a digitális hálózati média használója mégis egyszerre éli meg a magas szabadságfok és ellenőrizhetetlenség, valamint a végzetes és totális kontroll 
és megfigyeltség dichotómiáját. A megfigyelő - akárcsak Luhmann szociális rendszerelméletében - látja, amit a megfigyelt nem lát, mert nem is láthat. Az individuumnak már nem csupán begépelt vagy kattintott digitális jeleit regisztrálja a rendszer, hanem bionikus adatait is: tekintetének mozgását az előlapi kamerákon és a képernyők tetején ülő webkamerákon át, ujjlenyomatait az ujjlenyomat-olvasókon át, pulzusszámváltozását az aktivitásmérőjén át. Az ember és a gép közötti fizikai távolság egyre szűkül: ami elé a számítógépes ősidőkben le kellett ülnünk, azt később a táskánkban hordtuk magunkkal, majd kicsinyített formában a zsebünkbe költözött, utóbb pedig a csuklónkra vettük. A következő lépés logikusan adódik: testközelből a testre, testről pedig a testbe vándorol majd (majd?) a digitális eszköz. Egy ugrás választ el attól, hogy az okosóra helyett, amelynek gyorsulásmérő szenzora azonnal jelzi a családtagoknak, ha idős viselője bárhol a földre esett, testbe épített multiszenzorok mérjék a fizikai és biológiai kondíciót és akár egymással kommunikálva adjanak jelzést a hordozóik állapotáról.

Mindeközben az internethasználat helyszíne, amelyet sok esetben még ma is előszeretettel firtatnak a kérdőíves kutatások (például Nemzeti Médiaés Hírközlési Hatóság, 2020), egyre kevésbé releváns kérdés, hiszen az eszközeink egyre mobilabbak és egyre inkább ránk (illetve várhatóan belénk) költöznek. Ami azt illeti, az utóbbira már akadnak példák az IoT (Internet of Things) korszakában: nemcsak Elon Musk cégének kísérleteire kell gondolni, amelyek során sajtóhírek szerint sikerült gondolatirányítással vezérelni a számítógépet, hanem a bőr alá ültetett vércukorszintmérő szenzorokra, amelyek mobilapplikációba küldik az információt, vagy azokra a koponyába épített EEG-szerű érzékelőkre, amelyek lehetővé teszik, hogy viselőjük agyhullámok segítségével gépeljen szöveget a számítógépébe. A belénk épített hálózati eszközök drasztikusan átalakítják az internetezés helyéről alkotott elképzeléseinket: internetezünk mindenütt, ennélfogva sehol sem dedikáltan.

Nemcsak az internetezés fizikai helye függetlenedik a téri koordinátáktól, hanem az ideje is az időkoordinátáktól. Az internethasználat mennyisége napi, heti, havi stb. viszonylatban persze mérhető marad az aktív képernyőidő vizsgálatával, amely azt összesíti, hogy a tekintet mennyi időt tölt a képernyőre fókuszáltan. A zenei streamszolgáltatások terjedésével azonban aktív hallgatási időt is érdemes mérni, amely csak részben fed át az aktív képernyőidővel, vagy akár teljesen független is lehet tőle. Ráadásul az olyan digitális technológiák használati idejét mérni, amelyek képernyőt sem feltétlenül igényelnek, komoly kihívások elé állítja a kutatókat. Ameddig le kellett ülni a képernyők elé, és egy betárcsázási aktus során kellett csatlakozni a világhálóra, világos(abb)an és mérhető(bb)en különült el az internethasználat a többi cselekvéstől. Ezt segítette elő az is, hogy az internethasználat díja sok díjcsomagban napszakonként különböző volt. Ma, a flat rate díjcsomagok, a (nem egészen hálózatsemleges árképzéssel operáló) internetszolgáltatók és az always online generáció korában ez gyökeresen másképp van. A mérhetőség kérdése kapcsán gondoljunk például az Amazon Alexájára, amely leginkább 
egy internetre csatlakoztatott asztali hangszóróhoz hasonlít: hangutasításokkal vezérelhető, és vizuális helyett vokális, illetve - más hálózati eszközökön végrehajtott - cselekvéses válaszokat ad. Nem könnyü másodpercekben, percekben, órákban egyértelműen mérni, hogy a felhasználó tulajdonképpen mennyi időt is tölt ezzel az eszközzel, miközben használja.

Az ember-gép interakciók szabott ideje, úgy tűnik, véget ért, a két létező szimbiózisra lépett. Ezzel párhuzamosan a betárcsázás, a felcsatlakozás „beavatás”-jellege is eltűnt, a digitális hálózati média igénybevételéhez nem kell sem be-, sem „kimosakodnia” az egyénnek, hanem permanens jelenléttel, vagy legalábbis a jelenlét mindenkori elvi lehetőségével viszonyulhat hozzá. A digitális tér és a realitás tere két világ helyett egy, a digitális és a reális idő fluid (Bokor 2019).

Világunk a fokozott polikontexturalitás felé halad (Éber 2020): egyidejúleg kontextusok sokaságában kommunikálunk, s ezek közül nem választható ki egyetlen, igazi, abszolút pozíció (Karácsony 2001, 66.). Ez a struktúra alapjaiban két évtizede nem változott , csupán a kommunikáció sebessége fokozódott: ahogy az internethálózat újabb és újabb csomópontjai egyre-másra kapcsolatokat hoznak létre, és ezáltal „sűrítik” a hálózatba kötött számítógépek gráfját, a kontextusok sűrűsége ugyanúgy válik egyre fojtóbbá az individuum számára. Realitásrétegeink, másképp fogalmazva pervazív, de különösen passzazsér szerepeink (Buda 1994, 39-40.) áttekinthetősége egyre inkább csak illúzió, és ez nemcsak a társadalmi érintkezési formák változatossága miatt van így, hanem a technológia is elősegíti. Ráadásul a különböző online tevékenységek (például levelezés, keresés, olvasás, videomegtekintés stb.) a saját terek és saját idők különböző fajtáit, privát megéléseit hozzák létre; akkor is érvényesülnek és egyszerre vannak jelen, ha a „user” a saját kontextusából viszonyul hozzájuk. Így válik az internet közege szubjektív terek és idők polikontexturális hálójává.

Az internet többdimenziós jellegének megértését támogathatja Hartmann (1975) ontológiai rétegekről szóló megközelítése. Eszerint a létezőket mind jellemzi a szervetlen létezés, a fizikai létréteg, az anyag jelenléte és az annak tulajdonságait jellemző fizikai törvények működése. Erre épül rá az élő organizmusokat jellemző biológiai-organikus létréteg. Felépülése az alatta lévő létréteg törvényszerűségeinek megtartásával és átformálásával történik: az élő (biológiai) létezőkre a fizikai törvényszerűségek ugyanúgy hatnak, mint az élettelen létezőkre, ugyanakkor a biológiai működés egy sor olyan jellemző kialakulását feltételezi - például mozgás, lélegzés, anyagcsere, növekedés, reprodukció -, amelyek túlmutatnak a fizikai létrétegen. Hartmannál a harmadik réteg a pszichéé, amely a fizikai és biológiai létezésen túl tudati létezést kölcsönöz a létezőknek. Ennek a létrétegnek a törvényszerüségei eltérnek az organikus-biológiai lététől, de függőviszonyban vannak vele. Ha úgy tetszik: a biológiai létréteg hordozza a tőle elkülönülő, bizonyos viszonylatban mégis tőle függésben müködő tudati létréteget. Végül a szellemi lét következik, amely a puszta tudati létréteghez képest ismét többletet ad, spirituális dimenziókat 
nyitva meg: „a szellemi lét birodalma nem egyszerűen a tudati lét folytatása, és a réteg törvényszerűségeit nem lehet megmagyarázni pusztán a tudati élet törvényszerűségeiből” (Hartmann 2010).

Míg az emberi létezők mind a négy létrétegben mozognak, a gépi ágensek (nevezzük akár automatizált gépeknek, robotoknak vagy mesterséges intelligenciának ezt a csoportot) evidensen csak a fizikai létréteghez kötődnek, a biológiaihoz nem. Kérdéses viszont, hogy a tudati létréteg mennyire jellemzi a gépi ágenciát, az pedig még inkább a filozófia területére viszi a gondolkodót, hogy a szellemi létréteg birtoklására esélye nyílik-e valaha a gépeknek. (Ez az írás kívül esik azon a terjedelmen, szándékon és kompetenciakörön, amelyekkel ezt a problémát meg lehetne válaszolni.) Akárhogyan is, mindenképpen jellemzi a 2020-as éveket, hogy a fejlesztők kvázi-tudati és kvázi-szellemi létrétegszerűségekkel igyekeznek ellátni a gépi ágenseiket: ügyfélszolgálati chatbotok, adaptív kommunikációs rendszerek, személyre szabható virtuális tutorok produkálnak tudati-szerü és szellemi-szerü viselkedésmintákat, amelyek közelíteni igyekeznek egymáshoz a humán és gépi ágensek létréteg-struktúráját. Ez egyelőre csak a látszat szintjén működik, de ahogy Bostrom (2016) rámutat, a szingularitás jövőbeli elérésével a gépi intelligencia meghaladhatja az emberit, és ez akár a gépi ágensek tudati és szellemi kiérlelődését is maga után vonhatja. Addig, amíg ez megtörténik, a humán ágensek a digitális hálózati médiában azt tapasztalhatják, hogy a gépi ágensek már-már valódi partnerként jelennek meg számukra, egyenrangú kommunikációs helyzetekben, mintha rendelkeznének a tudat és a szellem létrétegeivel.

\section{A digitális nomád szállásterületének két arca}

„Digital nomadism is not always experienced as autonomous and free but is a way of living that requires high levels of discipline and self-discipline"

(Cook 2020).

Az internet használatával kezdettől fogva kéz a kézben járt a felhasználónak az a tapasztalata, hogy a tér és az idő, illetve a lokalitás fogalma és az időtudat átértelmeződött. Mindeközben a testtel való kommunikáció továbbra is csak korlátozottan fordítható át a szavak világába, hiszen „az érintést nem helyettesíti az emotikon” (Gacsályi 2021).

A metaforikus digitális nomád, aki egy be nem lakott területen, a virtuális valóság földjén vándorolva újabb és újabb szegleteket fedez fel, és előre megjósolhatatlan útvonalat jár be a hiperlinkeken ugrálva - immár a múlté. A 21. század digitális nomádjai és az általuk alkotott virtuális közösségek gondosan programozott viselkedéstriggerek mentén cselekednek még akkor is, ha többségük nincs tudatában ennek. E kiváltó ingerek összefoglaló neve brain-hacking, azaz a neurohormonális rendszer befolyásolása a digitális hálózati médiafelületek megfelelő designjának segítségével. Mikroszinten, 
a mindennapi internethasználat során - sok más mellett - az értesítések és állapotfrissítések megfelelő időzítése, makroszinten, az internetezés tágabb kontextusában pedig a személyes érdeklődésre hangolt tartalmak felkínálása teremti meg a szoros kötődést a virtualitáshoz. A humán ágensek sajátos biológiai és tudati működését kiaknázva a gépi ágensek - és persze humán tervezőik - sajátos kötődést alakítanak ki a felhasználóknál. Ennek következtében növekszik a szerotoninszint, és fellép a szorongásérzés, ha az okostelefont egy rövid időre eltávolítják a használójától. Ugyanennek következtében emelkedik a dopaminszint, és elönti a felhasználót a jó érzés, ha sok pozitív visszajelzést kap egy feltöltött tartalomra. Ugyanennek következtében érez a felhasználó ellenállhatatlan késztetést, hogy legritkábban ötpercenként ellenőrizze az értesítéseit a digitális eszközein, és nehogy lemaradjon valamiről (Przybylski et al. 2013). Ennélfogva a digitális nomád, aki, mint látható, biológiai létrétegébe ágyazottan cselekszik, csak nagy önfegyelemmel tudja kontrollálni azt, ahogyan a digitális lét hat rá - ha egyáltalán tudja.

De végső soron hogyan viszonyulnak a humán ágensek a digitális hálózati médiából kapott tartalmakhoz? Viszonyulásuk zavarba ejtően ellentmondásos képet mutat. Miközben a digitális képernyőidő összességében stabilan túllépte a televíziózással, rádiózással, újságolvasással, végső soron a klasszikus tömegkommunikációval töltött időt (Nemzeti Média- és Hírközlési Hatóság 2020), a tartalomfogyasztás közösségi élményét felváltották az egyéni tartalomfogyasztási útvonalak, az on demand tartalomfogyasztás, és ehhez az egyének privát médiagyakorlatokat alakítanak ki (Aczél, Andok és Bokor 2015; Couldry 2004). E tekintetben a nomád még nomádabb lett: immár még inkább jellemző, hogy magányosan vándorol a neten, mint korábban. Luhmann megfogalmazásában: „az internet nem tömegmédium” (Laurin 2008), a tömegesség helyett sokkal jellemzőbb rá a fragmentált, individuális tartalomfogyasztás. Másfelől a digitális hálózati média közösségi médiának nevezett része meggyőző karriert futott be a platformtípusok között: a digitális nomádoknak soha ilyen kiterjedt hálózati kapcsolatrendszere nem volt más humán ágensekkel, mint most. E tekintetben a nomád annyi társat kap(hat)ott a social mediában, amennyiről húsz éve még nem is álmod(hat)ott.

Ami a tartalmakba vetett hitet illeti, az szintén kétarcú: a digitális nomád szinte reflex-szerűen az említett online társas hálózatához fordul megszerezni a problémamegoldáshoz szükséges tudást, sőt bátran támaszkodik is arra. Hírportálok helyett a legtöbbjük inkább közösségimédia-hírfolyamokat olvas, amelyekben intézményi és privát ágensek tartalmai keverednek (Molnár 2014). ${ }^{3}$ Ugyanakkor egyre szkeptikusabban tekint általánosságban minden intézményes kommunikációra, különösen a politikaiakra, de sajnálatos módon a tudományosakra is, akár on-, akár offline találkozik azokkal (Székely 2018).

\footnotetext{
${ }^{3}$ Ezt példázza a marketingben az online márkarombolás, amely érkezhet intézményi (kollektív) és felhasználói (individuális) ágens felől egyaránt (Bokor 2014).
} 
A felhasználók által generált tartalmak valós idejủ előállítása és megosztása kezdetben a Wikipédia-projektben igyekezett konstruktívan testet ölteni. Minden vele kapcsolatos fenntartás ellenére - hiszen például akadémiai körökben a legtöbb intézményben kifejezetten ellenjavalltnak tartják az online szócikkek tudományos forrásként való idézését, felhasználását, és erre szocializálják a felsőoktatási hallgatókat is - a Wikipédia önmagában impozáns bizonyítéka a digitális nomádok kooperációjának, és annak, hogy az információk transzparens nyilvántartása elősegíti azok hitelességét: bár egy adott időpillanatban elképzelhető, hogy éppen fals információt látunk, annak javítására nem kell sokáig várni, ha a „közbölcsességet” működni engedjük. Mindez azonban csak olyan közegekben müködik, ahol az individuumoknak van kontrolljuk a közösség felett. Amennyiben azonban az intézmények nem biztosítják a tartalomelőállítás és -szerkesztés transzparenciáját, rejtett intenciók jelenhetnek meg a folyamat során, az individuumok kontrollja elvész, és végső soron megállapíthatatlanná válik, hogy a kapott információ hiteles-e vagy sem: az igazságtartalom kontigens és relatív lesz.

A digitális nomádok „szállásterületének” jelentős részét lefedő online hírszolgáltatás a Wikipédiától gyökeresen eltérő logika mentén működik: szűk intézményi kör (kapuőr) határozza meg, az igazság-hazugság bináris kódja így nehezen hozzáférhető. A fake news iparág, a kibermanipuláción alapuló diplomácia, a tudománykommunikáció válsága mind-mind erősíti azt a tézist, amelyet az itt-és-most tudásról két évtizede olvashattunk: minden tudás, amelyet az individuum a virtuális realitásban szerez, maga is virtuális, vagyis esetleges, lehetséges: felvehet egyes és nullás igazságértéket egyaránt, sőt - Schrödinger macskájához hasonlóan - akár a kettőt egyszerre is, az individuumok különböző olvasataitól függően. Az információk igazságértéke relativizálódik, bináris kódja erodálódik. A virtualitás igazságértéke megállapíthatatlan, egyszerre vehet fel különböző szubjektív igazság- és „hamisságértékeket”.

Az igazságkeresés sikerét nem segíti elő az sem, hogy a 2010-es évek végének hívószava, a deepfake-technológia immár nemcsak a felnőttfilmes iparág játékaként jut érvényre, hanem komoly digitálisalapú geopolitikai célokat szolgálhat: tanuló algoritmusok készítenek olyan politikusi nyilatkozatokat a virtuális térben, amelyek a realitásban sosem estek meg. Ugyanezek az ismert embereket és megnyilatkozásaikat olyan módon rekontextualizálják, hogy az a felületes szemlélő számára hiteles legyen. Sőt, a virtuális tér hétköznapi helyzeteiben is szembejönnek a valóságban nem létező, ugyanakkor létezőnek tűnő karakterek, hála például a „This person does not exist” projektnek. A tudás és a bizonyosság teljesen szubjektív és érzékek felett álló kategória lett.

A virtuális tér manapság Janus-arcú, mégpedig, ahogy láthattuk, a nomádok nomádsága és közösségisége, a tartalomfogyasztás egyéni és társas jellege, valamint a tartalmakba vetett hit szempontjából mindenképpen. Ezek mellett további két szempont teszi kétarcúvá a digitális nomádok „szállásterületét”. Először is humán és gépi ágensek viselkedései egyszerre formálják e „tájat”, egyszerre gyakorolnak rá hatást, karakterét együttesen alakítják ki. 
Másodszor, miközben továbbra is a korlátlan szabadság érzetét kínálja, a virtuális tér egyre növekvő mértékben tereli humán felhasználóit előre kialakított utakra, sarkallja őket előre megtervezett viselkedési minták követésére. Másképpen: ember és gép szimmetrikus ágenciájából a szabad, nomád vándorlás és a biológiai és tudati létrétegbe kötött individualitás egyszerre termelődik ki.

\section{Következtetés: új megbékélés felé}

Bár kezdetben úgy tűnt, hogy a mobil információs társadalom technológiái a modernségben nem hoztak sok változást az individualitás kifejeződése szempontjából, az elmúlt húsz év mégis árnyalta a képet. A virtualitás és realitás határán egyensúlyozó individuum már nem két világ polgára, hanem egyé, amely magába foglalja a konvergáló virtualitást és realitást. A digitális hálózati médiában (és médiával) töltött idő, valamint az internetezés helye egyre nehezebben mérhető meg objektív módszerekkel. Az individuum térés időészlelése ennek megfelelően válik viszonylagossá, tartalomfogyasztása pedig egyre inkább egyénivé. Ez az egyéniség azonban nem spontán, hanem tervezett: a digitális hálózati média -az individuumok biológiai és tudati létrétegeinek sajátosságaira építve - erős kontrollt gyakorol a felhasználók felett.

A digitális hálózati média humán ágensei mellett a hálózat technológiai gépi ágensei egyre önállóbbakká, mindinkább egyenrangú partnerekké válnak, a digitális hálózati média az ezredforduló kezdete óta a maga Janus-arcú módján mindinkább szűkíti az individuum önkifejezési lehetőségét. Bár az individuumok szellemi esszenciája (talán) továbbra is érintetlen a digitális hálózati médiától, a gépi ágencia mégis egyre erősebben formálja át őket, viselkedéseiket, gondolataikat, a tudásba vetett bizalmukat.

A tér- és időkereteket már nem uralják a „digitális nomádok”: a virtualitás és a realitás korábban szétválasztható színterei egyetlen világgá áll össze, amely meghatározza kereteinket. A digitális létünkből származó tudás hordozói csak nagyon kivételes esetekben személyesíthetők meg, ha egyáltalán humán ágenshez kötődnek. A tekintélyhez kötődő tudás helyett a hitek és a bizalom kerülnek előtérbe. A digitális hálózati média humán és gépi ágensei között új viszonyrendszer alakul ki.

A digitális nomád metaforája sem állja már meg a helyét: aki korábban egyedül vándorolt a feltáratlan, kiaknázatlan területeken, az most számtalan társsal együtt - úgy más individuumokkal, mint gépi ágensekkel -, de továbbra is egyéni útvonalakon halad, de szabadsága már csak látszólagos. Mind a biológiai működése, mind a társas túlélése, mind pedig a tudati folyamatai hozzákötik őt a digitális hálózathoz. E digitális létben, mint a példák mutatták, szaporodnak a gépi ágensek, amelyek korábban még jellemzően emberi szándékokat jelenítettek meg, de autonómiájuk fokozódásával immár nemcsak alárendeltjei lehetnek az individuumnak, hanem egyenrangú ágensként 
is megjelenhetnek - olykor emberi ágensnek álcázva magukat, olykor nyílt kártyákkal játszva és gépi ágensként mutatkozva. A jövőben ez a szimbiózis fokozódni látszik. Így a digitális hálózati média következő húsz éve, könnyen lehet, annak története lesz majd, hogyan tud megbékélni egymással emberi és gépi intelligencia, és hogyan kínálnak fel egymásnak újabb megoldásokat az individuum kifejeződésére.

\section{Köszönetnyilvánítás}

A szerző köszönettel tartozik Gálik Mihály professor emeritusnak, amiért valamikor a 2010-es évek első felében figyelmébe ajánlotta a bevett „újmédia” és „mobil információs technológia” terminusok precíz helyettesítőjeként a „digitális hálózati média” fogalmát, továbbá amiért szerkesztési és tartalmi tanácsokkal látta el a szerzőt e cikk születésekor.

Karácsony András nemcsak a digitális nomádokról szóló 2001-es írással, hanem a szerző doktori dolgozatának egykori témavezetésével, majd e cikk értő olvasásával, előzetes véleményezésével is rengeteget segített. Nézete szerint, amíg a fizikai világban is lehetséges álca (maszkírozás, hamis név), addig a digitális hálózati médiában ez most már rutinszerű feladat, amelynél a lebukás veszélye minimális. Épp ezért nehezebb ma már párhuzamba állítani a kibervilágot a realitással, mint húsz évvel ezelőtt.

Szintén köszönet illeti Ropolyi Lászlót, aki a technikafilozófia szemszögéből értékelte ezt az írást, és eközben számos megfontolandó gondolatot fogalmazott meg a virtualitásról mint mértékkel rendelkező valóságról, a nethasználatról mint alapvető és legfontosabb személyiségformáló tényezőről, valamint arról, hogy a mesterséges intelligencia átlépi-e valaha az ember és a gép közti határvonalat. Minden bizonytalanság ellenére is biztató, hogy ezek a kérdések valódi kérdések még, s mint ilyenek, sok-sok további gondolkodást igényelnek a jövőben.

\section{Irodalom}

Aczél Petra, Andok Mónika és Bokor Tamás. Múveljük a médiát. Budapest: Wolters Kluwer Kiadó, 2015.https://buvosvolgy.hu/dokumentum/108/aczel muveljuk a mediat.pdf

Bokor Tamás. „Posztmodern nomádok. Virtuális közösségek a realitásban.” In Magyar Kommunikációtudományi Társaság 2010.június 11-12-i, „Közösségek mai (kommunikációs) arculata” című konferenciájára, Budapesti Műszaki és Gazdaságtudományi Egyetem, 2010. http://unipub.lib.uni-corvinus.hu/2875/1/mktt_szoveg.pdf 
Bokor Tamás. Humán online társadalmi kommunikáció. Internetes szociális rendszerek rekonstrukciója a nyilvánosság és a közösségképződés kontextusában. Doktori értekezés. Pécs: Pécsi Tudományegyetem, 2011. https://pea.lib.pte.hu/bitstream/handle/pea/15323/ bokor-tamas-phd-2012.pdf?sequence=1\&isAllowed=y

Bokor Tamás. „More than Words, Brand Destruction in the Online Sphere.” Vezetéstudomány - Budapest Management Review 45, no. 2 (2014): 40-45.

https://doi.org/10.14267/VEZTUD.2014.02.06

Bokor Tamás. „From Digital Cradle to Virtual Grave Ethical Challenges in the Real-Virtual World.” In Ahmet Ayhan (szerk.). New approaches in media and communication. Bern: Peter Lang, 2019.

Bostrom, Nick. Superintelligence: Paths, dangers, strategies. Oxford: Oxford University Press, 2016.

Brooker, Charlie. Black Mirror (3. Évad) [Science fiction; Stream]. Netflix. 2016.

Buda Béla. A közvetlen emberi kommunikáció szabályszerüségei. Budapest: Animula Kiadó, 1994.

Castells, Manuel. The Internet Galaxy: Reflections on the Internet, Business, and Society. Oxford: Oxford University Press, 2001.

Cook, Dave. „The freedom trap: Digital nomads and the use of disciplining practices to manage work/leisure boundaries.” Information Technology \& Tourism 22, no. 3 (2020): 355-390. https://doi.org/10.1007/s40558-020-00172-4

Couldry, Nick. „Theorising media as practice.” Social Semiotics 14, no. 2 (2004): 115-132. https://doi.org/10.1080/1035033042000238295

DiMaggio, Paul, Hargittai Eszter, W. Russell Neuman és John P. Robinson. „Social Implications of the Internet.” Annual Review of Sociology 27, no. 1 (2001): 307-336.

https://doi.org/10.1146/annurev.soc.27.1.307

Éber Márk Áron. „A rendszer fáj a földnek: Ökológiai problémák és kommunikációjuk kétféle rendszerfelfogásban.” Replika 114. szám (2020): 41-61. https://doi.org/10.32564/114.2

Osha.europa.eu. European Agency for Safety \& Health at Work. „Áttekintés a munka jövőjéről: Robotika.” Utolsó hozzáférés: 2021. április 30.

https://osha.europa.eu/hu/publications/future-work-robotics

Mandiner. Gacsályi Sára. „Az érintést nem helyettesíti az emotikon.” Utolsó hozzáférés: 2021. április 30. https://mandiner.hu/cikk/20210210 az erintest nem helyettesiti az emotikon

Hartmann, Nicolai. New ways of ontology. Westport, Connecticut: Greenwood Press, 1975.

Hartmann, Nicolai. Ethik (4., unveränd. Aufl, Rep.2010). Berlin: De Gruyter, 2010.

Helmond, Anne. „The Platformization of the Web: Making Web Data Platform Ready.” Social Media + Society 1, no.2 (2015), 205630511560308. https://doi.org/10.1177/2056305115603080

Karácsony András. „Individualitás a nomádok földjén.” Információs Társadalom I, 1. szám (2001): 61-67.

DOI: http://dx.doi.org/10.22503/inftars.I.2001.1.5

Ruhrbarone. Laurin, Von Stefan. „Interview mit Niklas Luhmann: ?Das Internet ist kein Massenmedium?” Utolsó hozzáférés: 2021. április 30. https://www.ruhrbarone.de/niklasluhmann-,.das-internet-ist-kein-massenmedium"/1109

Castells, Manuel. The Internet Galaxy: Reflections on the Internet, Business, and Society. Oxford: Oxford University Press, 2001. 
Luhmann, Niklas. Szociális rendszerek. Budapest: Gondolat Kiadó, 2009.

Manovich, Lev. The language of new media. Cambridge, Massachusetts: MIT Press, 2001.

McLuhan, Marshall. A Gutenberg-galaxis: A tipográfiai ember létrejötte. Budapest: Trezor Kiadó, 2001.

Molnár Attila Károly. „Arctalan hangok.” In Lányi András és László Miklós (Szerk.). Se vele, se nélküle? - Tanulmányok a médiáról, 51-83. Budapest: Wolters Kluwer Kiadó, 2014.

NMHH. Nemzeti Média- és Hírközlési Hatóság. „Az elektronikus hírközlési piac fogyasztóinak vizsgálata. Internetes felmérés - 2019.” Utolsó hozzáférés: 2021. április 30. https://nmhh. hu/dokumentum/212534/internet 2019 tanulmany.pdf

Orlowsky, Jeff. Social Dilemma [Documentary; Stream]. Netflix. 2020 https://www. thesocialdilemma.com

Przybylski, Andrew K., Kou Murayama, Cody R. DeHaan, \& Valerie Gladwell. „Motivational, emotional, and behavioral correlates of fear of missing out." Computers in Human Behavior 29, no. 4 (2013), 1841-1848. https://doi.org/10.1016/j.chb.2013.02.014

Ropolyi László. „Digitális identitás-E-személyiség.” In Daróczi Enikő és Laczkó Sándor (Szerk.). Lábjegyzetek Platónhoz 18. Az identitás, 245-259. Szeged: Pro Philosophia Szegediensi Alapítvány, Magyar Filozófiai Társaság, Státus Kiadó, 2020.

Székely Levente (szerk.). Magyar fiatalok a Kárpát-medencében: Magyar Ifjúság Kutatás 2016. Budapest: ENIGMA 2001. Kiadó és Médiaszolgáltató KFT., 2018.

https://www.researchgate.net/profile/Eleonora-Szanyi-F/publication/328610670 Iskolapadbol a munkaeropiacra - magyar_fiatalok karrierpalyaszakaszainak elemzese/ links/5c04feb2a6fdcc74c846b788/Iskolapadbol-a-munkaeropiacra-magyar-fiatalokkarrierpalyaszakaszainak-elemzese.pdf

Turkle, Sherry. „Cyberspace and Identity.” Contemporary Sociology 28, no 6. (1999): 643-648. https://doi.org/10.2307/2655534

Varga János. (szerk.). 20 éves a magyarországi internet: Ahogy a szakemberek megélték, megélik. (Budapest): Internet Szolgáltatók Tanácsa, 2011. 